\title{
KETAHANAN TUMBUH PERMUDAAN RAMIN DI GENEPOOL RAMIN DI SPTN WILAYAH I KAWASAN TAMAN NASIONAL SEBANGAU KALIMANTAN TENGAH
}

\section{(Ramin (Gonystylus bancanus) Growth Endurance in Ramin Genepool Area SPTN Wilayah I Sebangau National Park of Kalimantan Tengah)}

\author{
Siti Maimunah ${ }^{1)}$ dan Nina Maryana ${ }^{2)}$ \\ 1) Dosen Program Studi Kehutanan Fakultas Pertanian dan Kehutanan Universitas Muhammadiyah Palangkaraya \\ 2) Alumni Program Studi Kehutanan Fakultas Pertanian dan Kehutanan Universitas Muhammadiyah Palangkaraya \\ e-mail : sitimararil@gmail.com
}

\begin{abstract}
Ramin's growth and development is very slowly and have many inhibited factore, there are seed specific character with hard coating, too difficult for vegetative propagation, and limited abundant because seedling is very depend to sustainable nature, so there are caused how ramin is rare now. Ramin propagation have done in Sebangau National Park in 2010 with 5 ha wide area of Genepoolin two areas, 3ha area inSungai Koran and 2 ha in Stasiun Riset Lapangan (SSI). In Genepool area development hasn't have database for growth and development of ramin. This research aim are to monitoring and evaluation growth endurance and to know how about ramin to decreasing in Genepool area.

The parameter of this research is growth endurance, high, diameter and laef growth of Ramin seedling, pest and diseases. Growth endurance percentase for 5 year of growth is 60,70\%, average of high 1,42 m, average of diameter 1,69 cm, average of leaf growth 17,61 helai, existence of pest and diseases is insecta attack and human activity. Need a socialiszationabout Genepool existence for minimizing ramin damaged caused human activities.
\end{abstract}

Keywords : genepool, ramin, growth and development

\begin{abstract}
Abstrak
Pertumbuhan dan perkembangan ramin sangat lambat dan banyak kendala seperti sulitnya diperbanyak baik generatif maupun vegetatif dan hanya tergantung pada permudaan alam yang sangat terbatas sehingga mempengaruhi kelangkaan jenis ini serta kualitas genetik turunan yang belum jelas. Perbanyakan ramin dilakukan oleh Taman Nasional Sebangau pada tahun 2010 dengan pembuatan Genepool seluas 5 ha yaitu di Sungai Koran seluas 3 ha dan di Stasiun Riset Lapangan (SSI) seluas 2 ha. Dalam pembangunan Genepool tersebut belum dilakukan pendataan secara intensif sehingga penelitian ini bertujuan untuk mengumpulkan data tingkat ketahanan tumbuh permudaan ramin dan penyebab kematian permudaan ramin di lokasi genepool ramin di SPTN Wilayah I kawasan Taman Nasional Sebangau. Manfaat penelitian ini adalah monitoring dan evaluasi ketahanan tumbuh permudaan ramin dan mengetahui penyebab kematian permudaan ramin di lokasi genepool ramin.

Parameter yang diamati antara lain adalah persentase ketahanan tumbuh bibit, tinggi bibit, diameter bibit, jumlah daun dan data mengenai organisme pengganggu tanaman (OPT). Persentase ketahanan tumbuh bibit selama lima tahun mencapai $60,70 \%$, tinggi rataan $1,42 \mathrm{~m}$, rataan diameter 1,69 cm, rataan jumlah daun 17,61 helai, keberadaan OPT antara lain serangan hama berupa bekas serangan serangga dan bekas perusakan oleh aktivitas manusia. Perlu dilakukan sosialisasi keberadaan genepool utuk mengurangi tingkat kerusakan tanaman ramin yang disebabkan oleh aktivitas manusia.
\end{abstract}

Kata kunci :genepool, ramin, pertumbuhan dan perkembangan

\section{PENDAHULUAN}

Taman Nasional Sebangau sebagai habitat asli ramin memiliki peran yang sangat penting dalam konservasi in-situ ramin termasuk ekosistem dimana tumbuhan tersebut tumbuh dan berkembang sehingga dapat menunjang sarana pendidikan, penelitian, wisata dan sumber plasma nutfah yang saat ini telah mulai langka diseluruh tipe hutan gambut di Indonesia (BTNS, 2007). Kerjasama 
dilakukan antara Taman Nasional Sebangau dengan BPK Banjarbaru dan ITTO (International Tropical Timber Organization)CITES Project sebagai Areal Sumber Daya Genetik (ASDG) melalui strategi konservasi insitu dan atau mendukung konservasi $e x$-situ.

Permasalahan yang dihadapi di lapangan dalam pengelolaan dan konservasi ramin diantaranya adalah pengelolaan hutan alam yang masuk dalam CITES belum dilaksanakan sesuai dengan kaidah pengelolaan hutan lestari, kebakaran hutan rawa gambut atau habitat alami ramin yang terjadi hampir setiap tahun belum dapat diatasi dengan baik, regenerasi ramin di hutan alam masih sangat rendah, upaya penanaman ramin masih sangat terbatas, penguasaan terhadap teknologi pendukung pengelolaan hutan alam ramin masih sangat terbatas dan rendahnya kesadaran masyarakat tentang pentingnya fungsi ekosistem hutan alam ramin (ITTO, 2009).

Mengingat pertumbuhan ramin yang sangat lambat dan ketersediaan di alam semakin berkurang maka dalam upaya konservasi harus ditingkatkan pelestariannya. Dengan demikian penyelamatan dan pemulihan pohon ramin harus dilakukan dengan bantuan manusia dan hingga saat ini rehabilitasi ramin masih sangat terbatas. Upaya pelestarian yang sedang berjalan hingga saat ini belum diketahui tingkat ketahanan permudaan ramin dan belum diketahui penyebab matinya permudaan ramin dilokasi genepool ramin. Karena itu untuk mengetahui ketahanan dan penyebab kematian permudaan ramin perlu dilakukan pengamatan dan penelitian ketahanan permudaan ramin di lokasi genepool ramin di Kawasan Taman Nasional Sebangau.

Tujuan peelitian ini adalah untuk mengetahui tingkat ketahanan tumbuh permudaan ramin dan mengetahui penyebab kematian permudaan ramin di lokasi genepool ramin di SPTN Wilayah I kawasan Taman Nasional Sebangau. Sedangkan manfaat yang diharapkan adalah untuk monitoring dan evaluasi ketahanan tumbuh permudaan ramin di lokasi genepool ramin dan mengetahui penyebab kematian permudaan ramin di lokasi genepool ramin.

\section{METODOLOGI}

Penelitian ini dilakukan di lokasi genepool ramin dengan luas 3 ha di kawasan Resort Sebangau Hulu, SPTN Wilayah I Palangka Raya Taman Nasional Sebangau Provinsi Kalimantan Tengah. Waktu yang diperlukan dalam penelitian yaitu bulan Oktober 2015 sampai dengan Desember 2015.

Bahan yang digunakan dalam penelitian ini adalah bibit ramin yang berada dilokasi genepool ramin. Bibit yang diperoleh berasal dari cabutan bibit liar di dalam kawasan Taman Nasional Sebangau dengan jarak tanam bibit $5 \times 3 \mathrm{~m}$, jarak antara jalur $5 \mathrm{~m}$. Terdapat 40 jalur, disetiap jalur ditanam 50 bibit ramin, jumlah bibit ramin yang berada di lokasi genepool ramin sebanyak 2000 bibit. Alat penelitian meliputi rollmeter, caliper, tallysheet, dan camera. 


\section{Prosedur Penelitian}

1. Persiapan Penelitian

Mengumpulkan data sekunder berupa data kondisi hidup dan mati bibit ramin dari tahun 2010, 2012 dan 2013 (sumber laporan kegiatan BTNS).

2. Sensus Bibit

Pada setiap jalur dilakukan pengamatan sensus terhadap bibit yang telah ditanam secara satu per satu untuk diketahui bibit yang hidup atau mati di lokasi genepool ramin. Kemudian dipilih 10 pohon sampling secara acak dari setiap jalur untuk mewakili keterwakilan kondisi permudaan ramin dengan beberapa pengukuran parameter yang diamati seperti ketahanan tumbuh semai (\%), tinggi bibit $(\mathrm{m})$, diameter bibit $(\mathrm{cm})$, jumlah daun pada bibit (helai). Dari pengamatan di lapangan akan diperoleh 400 bibit sampling. Apabila terdapat permudaan ramin yang mati akan dicatat penyebab kematiannya oleh hama/penyakit atau yang disebabkan oleh cekaman.

Data sekunder diperoleh di lapangan pada tahun 2010, 2012 dan 2013. Tahun 2010 diperoleh data bibit hidup 2050, tahun 2011 dan 2014 tidak dilakukan monitoring sehingga tidak ada data, tahun 2012 diperoleh jumlah bibit ramin yang mati 883 dan bibit ramin yang hidup 1167, sedangkan untuk tahun 2013 diperoleh jumlah bibit ramin yang mati 1016 dan bibit ramin yang hidup 1034 (Wagiso et. al., 2012 dan 2013).
Tabel 1. Kondisi bibit ramin pada saat monitoring tahun 2010, 2012 dan 2013

\begin{tabular}{|c|c|c|c|}
\hline Tahun & Kond & Bibit & Total \\
\hline Pengamatan & Hidup & Mati & Bibit \\
\hline 2010 & 2050 & - & 2050 \\
\hline 2012 & 1167 & 883 & 2050 \\
\hline 2013 & 1034 & 1016 & 2050 \\
\hline
\end{tabular}

\section{HASIL DAN PEMBAHASAN}

Berdasarkan hasil pengamatan diperoleh persentase ketahanan tumbuh bibit ramin di lokasi genepool ramin setelah lima tahun sebesar 60,70\% (1214) bibit hidup dan $39 \%$ (786) bibit mati sesuai Gambar 1.

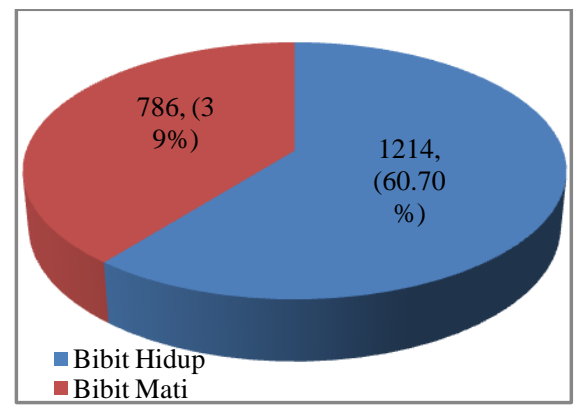

Gambar 1. Grafik persentase ketahanan tumbuh bibit setelah 5 tahun

Persentase tumbuh bibit ramin tidak mencapai $100 \%$ hal ini dikarenakan pada saat dilapangan ditemukan bibit yang mati karena kekeringan, bibit yang hilang dan bibit yang terkena tebasan. Pada lokasi penanaman bibit ramin tidak semua jalur yang ternaungi oleh pepohonan yang besar karena disekitar lokasi merupakan areal bekas kebakaran dan bekas illegal logging. Di lokasi penanaman genepool ramin memiliki kondisi lapangan yang berbeda-beda 


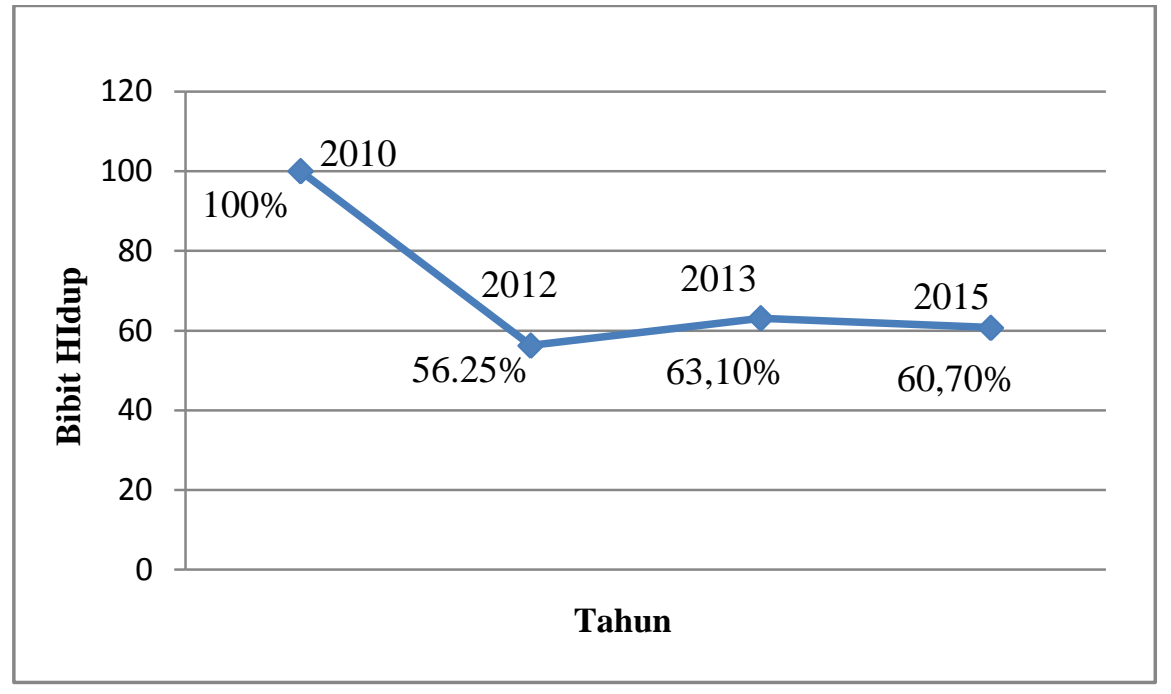

Gambar 2. Persentase ketahanan hidup bibit ramin

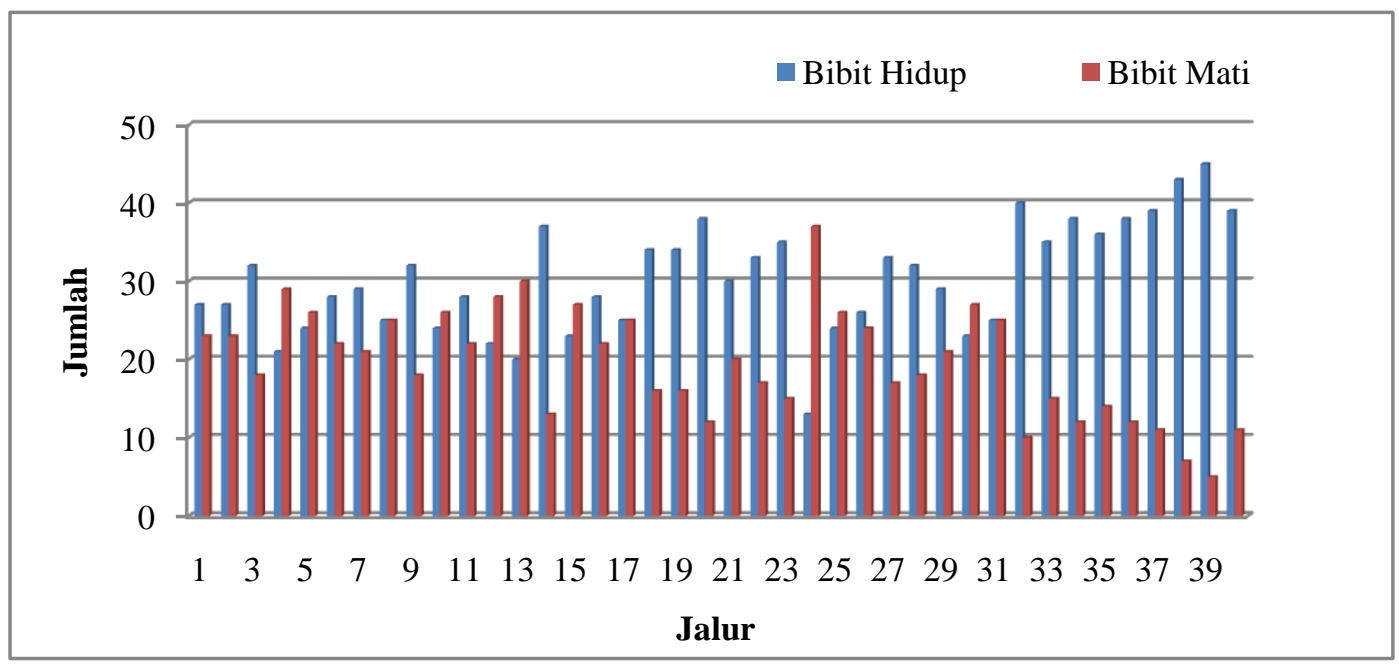

Gambar 3. Grafik pertumbuhan bibit ramin setelah 5 tahun

yaitu ada yang berada pada lokasi agak ternaung dan ada yang berada pada lokasi agak terbuka.

Banyak bibit yang hilang pada jalur ke-24 dimungkinkan karena pada saat penyulaman tahun 2013 tidak tertanam atau bibit telah mati tanpa meninggalkan bekas sehingga dianggap hilang.
Jalur ke-39 menunjukan angka hidup bibit ramin lebih tinggi dari pada jalur lainnya yaitu 45 bibit hidup dan 5 bibit mati. Ramin merupakan jenis semitoleran, sehingga membutuhkan intensitas cahaya (naungan) tertentu, terutama pada tingkat semai (Muin, 2009). Di lapangan bibit ramin pada jalur ke-39 banyak ternaungi oleh pohon-pohon besar yang berada disekitarnya dan karena tidak ada pemeliharaan pada tahun 2014 bibit ramin yang 
ditemukan banyak ditumbuhi semak belukar dan kondisi di dalam lebih lembab. Bibit mati yang ditemukan pada jalur ini bukan akibat cekaman kekeringan atau hama penyakit melainkan karena bibit hilang, hanya ditemukan ajir dan nomor pohon.

Grafik pertumbuhan ramin setelah 5 tahun menunjukkan hasil bibit ramin yang hidup lebih banyak pada jalur 32 sampai dengan jalur 40 hal ini dikarenakan pada jalur tersebut cahaya matahari ternaungi dengan keberadaan pohon - pohon yang tinggi disekitar jalur sehingga memungkinkan bibit ramin untuk lebih tahan tumbuh dibandingkan dengan lokasi yang terbuka seperti pada jalur 1 dan jalur 2 yang lokasinya terbuka. Patok batas lokasi genepool ramin berada di jalur ke-40 sehingga pengamatan dilakukan hanya sampai jalur ke-40 bukan ke jalur 41 seperti di dalam proposal yang dibuat.

\section{Menurut Warsopranoto 1975 dalam} Komar dkk 2010, mengingat anakan ramin di waktu muda butuh naungan maka penanamannya dilakukan dengan cara schaduw rijen cultuur artinya penanamannya di bawah naungan dalam bentuk jalur-jalur tanam.

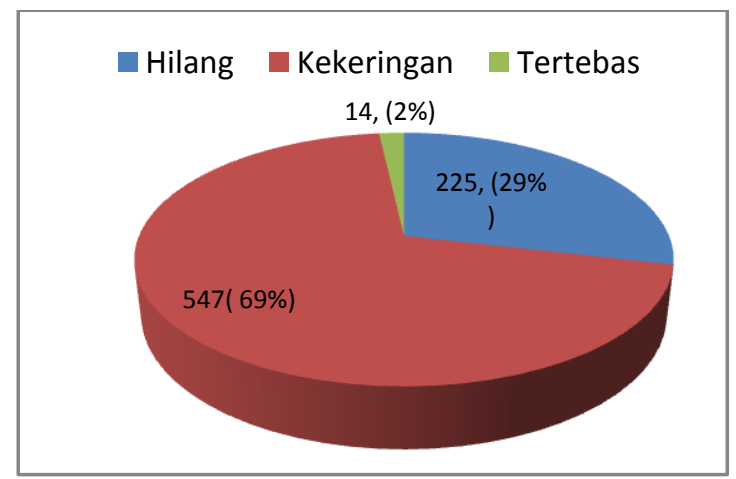

Gambar 4. Grafik penyebab kematian bibit ramin tahun 2015
Gambar 4 menunjukkan penyebab kematian bibit ramin di lokasi genepool Ramin, jumlah bibit ramin yang hilang sebanyak 225 bibit (29\%), jumlah bibit ramin yang kekeringan sebanyak 547 bibit (69\%) dan jumlah bibit yang tertebas sebanyak 14 bibit (2\%). Kematian bibit yang terjadi lebih banyak didominasi oleh bibit yang terkena kekeringan atau cekaman sebesar $69 \%$, di lokasi penelitian ditemukan bibitnya masih ada tetapi dalam kondisi mati dan kekeringan. Ditandai dengan tidak adanya daun yang hidup, patah batang dan mati pucuk. Cekaman atau kekeringan yang terjadi dikarenakan pada bulan September 2015 disekitar lokasi penanaman Genepool Ramin terjadi kebakaran hutan yang luas dan cukup lama sehingga menyebabkan suhu disekitar lokasi menjadi meningkat panas. Bibit yang mati karena hilang sebesar 29\%, di lokasi penelitian hanya ditemukan ajir atau nomor bibitnya saja. Tidak diketahui penyebab bibit hilang, dimungkinkan karena mati dan patah tetapi bekas bibit tidak ditemukan. Aktivitas manusia yang berada disekitar lokasi genepool ramin dapat mengganggu pertumbuhan dan perkembangan bibit ramin yang telah ada.

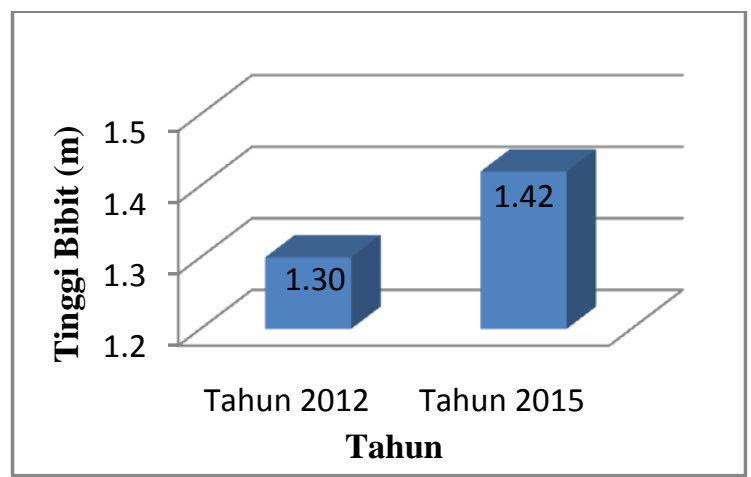

Gambar 5. Grafik rerata tinggi bibit tahun 2012 dan tahun 2015 


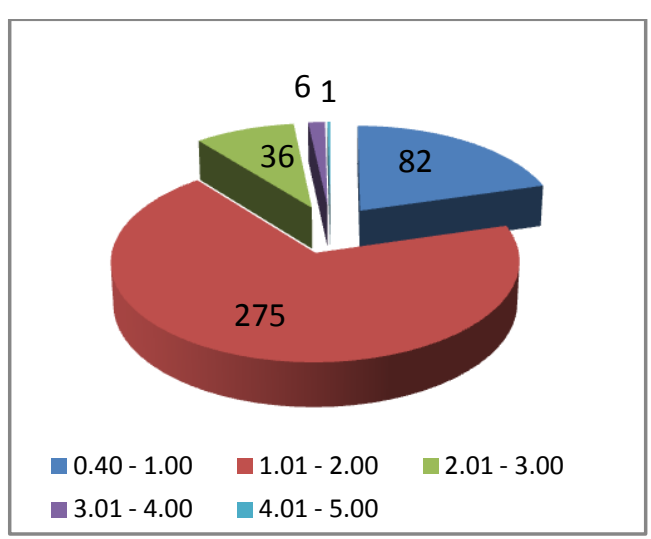

Gambar 6. Sebaran pertumbuhan tinggi bibit ramin $(\mathrm{m})$ tahun 2015

Bibit yang berada pada kelas 4,01 - 5,00 $\mathrm{m}$ merupakan bibit yang tumbuh dari tahun 2010 sampai dengan 2015 karena kelas tingginya berbeda dengan kelas tinggi yang lain, bibit yang tingginya $5,00 \mathrm{~m}$ terdapat pada jalur ke-11.

Berdasarkan data yang diperoleh dari lapangan, hasil rerata diameter bibit ramin selama lima tahun adalah 1,69 $\mathrm{cm}$. Diameter rerata bibit terendah sebesar $0,96 \mathrm{~cm}$ yaitu pada jalur ke-35 dan pada jalur ke-29 menunjukkan rerata bibit terendah $1,11 \mathrm{~cm}$, tersaji pada Gambar 7.
Pada jalur ke-10 disekitar lokasi agak terbuka sehingga memungkinkan lebih banyak intensitas cahaya yang masuk ke lantai hutan. Begitu pula dengan jalur pertama yang lokasinya agak terbuka. Jalur ke-35 berada di lokasi yang agak ternaung oleh pohon-pohon tinggi sehingga kelembabannya lebih tinggi. Besarnya intensitas cahaya yang diterima telah cukup dan lebih bebas dari himpitan atau gangguan tanaman dari bagian samping atau sekitarnya mengakibatkan pertumbuhan tanaman ke arah samping terganggu/tertekan.

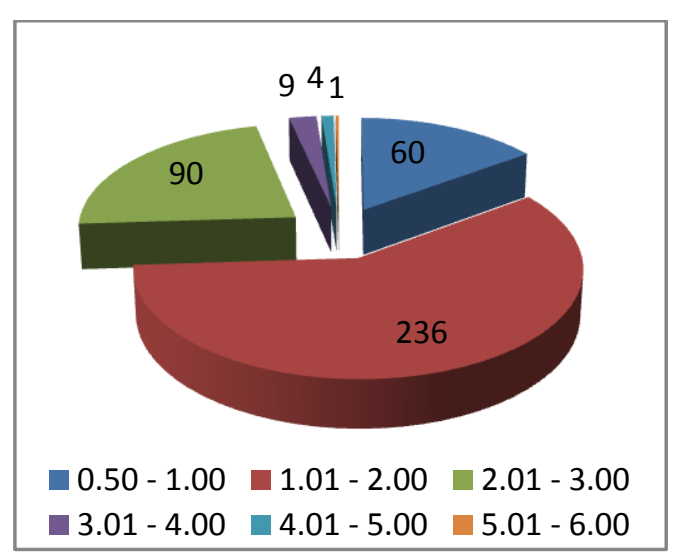

Gambar 8. Sebaran pertumbuhan diameter $(\mathrm{cm})$ bibit ramin

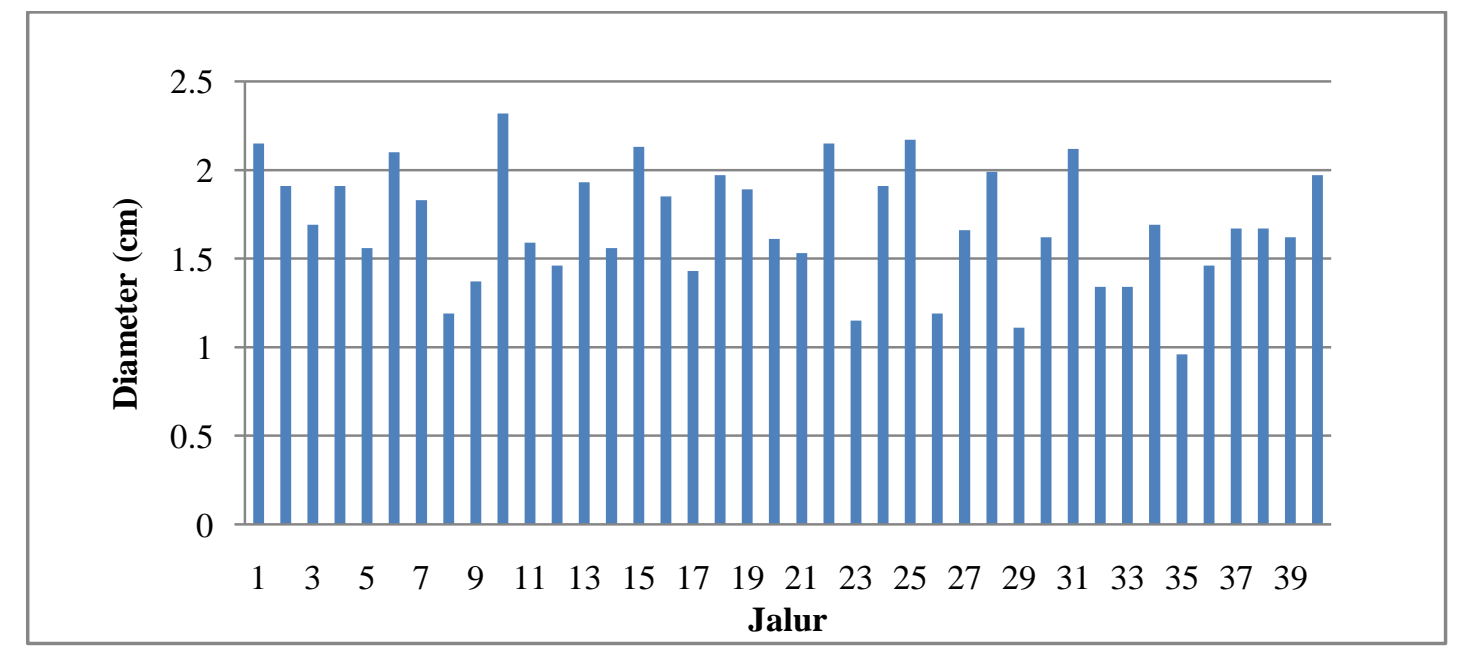

Gambar 7. Rerata diameter (cm) bibit ramin 
Daun merupakan bagian dari tanaman yang sangat penting, karena klorofil pada daun adalah bahan utama penting untuk proses fotosintesis. Pada Gambar 9 menunjukkan rerata jumlah daun (helai) bibit ramin setelah 5 tahun dari 40 jalur di lokasi genepool ramin. Rerata tertinggi berada pada jalur ke-25 dan jalur ke-38 dengan rerata jumlah daun yang sama yaitu 29,6 sedangkan jalur ke-9 dan jalur ke-23 menunjukan jumlah rerata jumlah daun terendah sebesar 10,2 helai. Tidak ada pembanding rerata jumlah daun dari mulai tahun pertama penanaman yaitu tahun 2010 sampai tahun 2014.

Kelas sebaran jumlah daun yang mendominasi terdapat pada kelas sebaran 1 - 15 helai yaitu 239 bibit dan kelas yang jumlah yang paling sedikit terdapat pada kelas 106 - 120 helai hanya 1 bibit.

Menurut Dwijoseputro 1983 dalam Milang dkk 2013, faktor lingkungan yang baik menyebabkan proses pembentukan daun

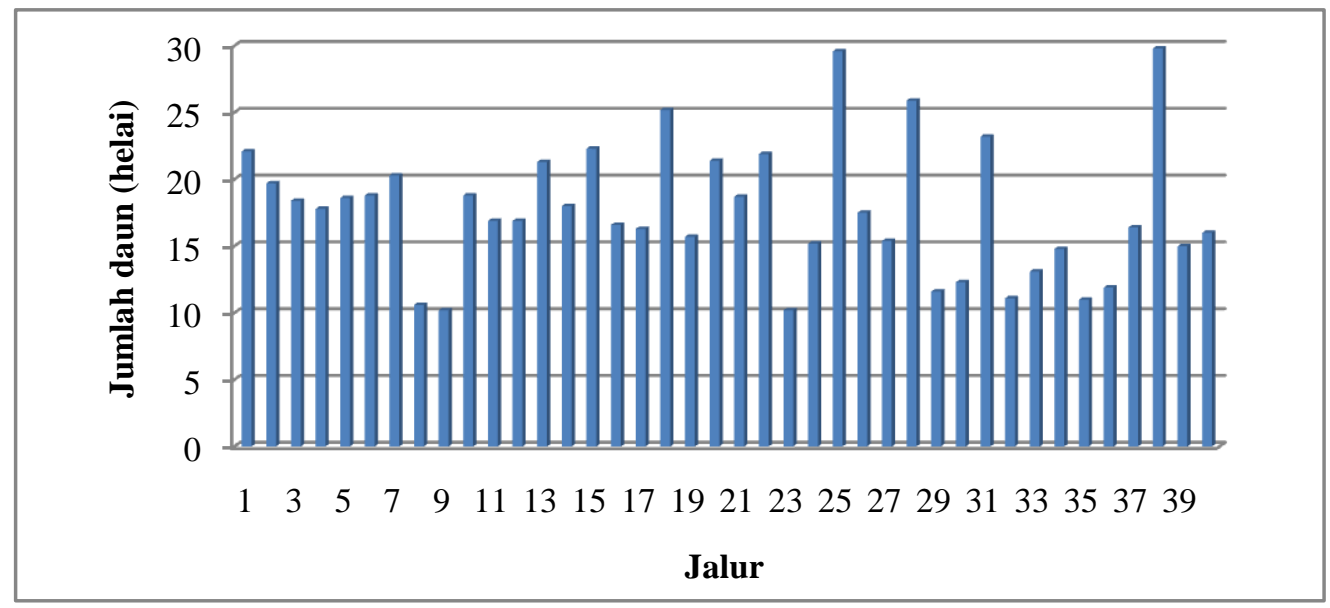

(a)

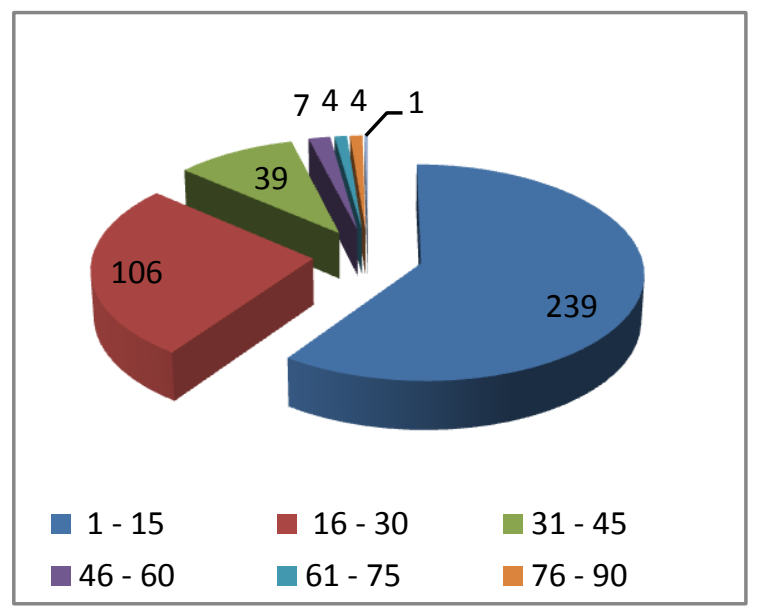

(b)

Gambar 9. (a) Rerata jumlah daun (helai); (b) Sebaran pertumbuhan jumlah daun (helai) 
berlangsung dengan baik. Tumbuhan yang memiliki jumlah daun yang banyak akan sangat membantu proses fotosintesis berjalan dengan baik. Salah satu tanda poduktivitas adalah kemampuan memproduksi daun, sebab daun merupakan tempat terjadinya proses fotosintesis. Jumlah daun suatu tanaman berhubungan dengan intensitas fotosintesis.

Pada saat pengamatan di lapangan ditemukan beberapa bibit yang daunnya dimakan oleh binatang. Tidak ditemukan bibit yang mati karena hama atau penyakit. Dilihat dari bekas gigitan dan kerusakan yang ditimbulkan pada daun bibit ramin diindikasikan oleh serangga. Kerusakan yang terjadi tidak menyebabkan bibit ramin mati, bibit ramin hanya mengalami kerusakan pada daun baik ditepi daun maupun pada bagian dalam daun. Serangga tidak hanya merusak bagian daun muda tetapi semua daun yang ada pada bibit tersebut. Faktor penyebab kematian bibit ramin yang dominan karena kekeringan sebesar 69\% atau 547 bibit, kematian bibit lainnya karena hilang dan kena tebasan.
Pada jalur ke-4 dan jalur ke-30 bibit ramin banyak mengalami cekaman kekeringan sebesar 25 bibit. Jalur yang tidak mengalami cekaman kekeringan terdapat pada jalur ke-39, jalur ini berada pada jalur yang agak ternaungi. Jika dilihat dari grafik diatas maka akan terlihat angka yang berbeda setiap jalur. Menurut Lisar et al. (2012) dalam Sinay (2015) akibat cekaman kekeringan pada tanaman yaitu penutupan stomata, penurunan laju fotosintesis dan laju transpirasi, penurunan laju penyerapan dan translokasi nutrien (unsur hara), penurunan pemanjangan sel, serta penghambatan pertumbuhan. Jumlah garam yang tinggi pada media akan menurunkan potensial osmotik sehingga tanaman kesulitan menyerap air sehingga menyebabkannya kekeringan fisiologis. Apabila perakarannya tidak berfungsi, makapenyerapan unsur hara akan terganggu.

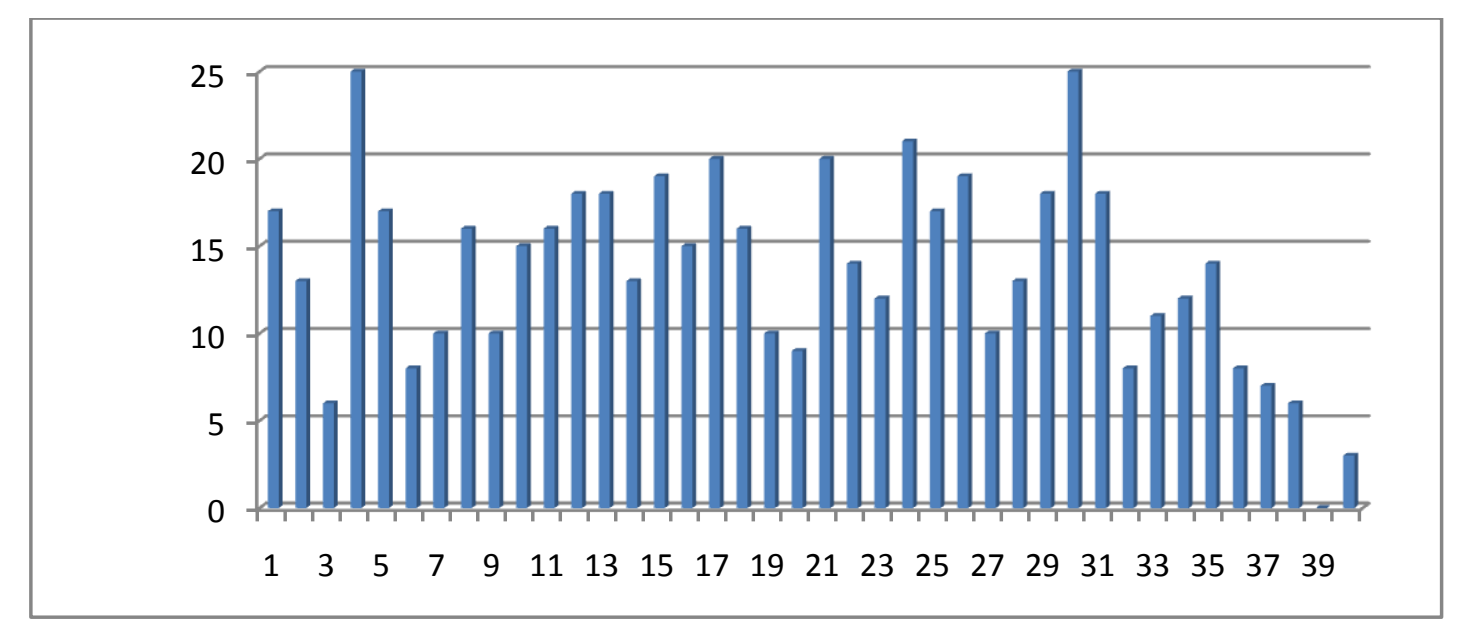

Gambar 10. Jalur yang mengalami cekaman kekeringan 


\section{SIMPULAN DAN SARAN}

\section{Simpulan}

1. Pertumbuhan ramin selama lima tahun memiliki persentase hidup sebesar $60,70 \%$ sedangkan untuk persentase bibit mati sebesar $39 \%$.

2. Penyebab kematian bibit ramin $67 \%$ disebabkan oleh kekeringan, 31\% karena hilang dan $2 \%$ kena tebasan.

3. Rerata pertumbuhan tinggi bibit ramin $1,40 \mathrm{~m}$, rerata pertumbuhan diameter bibit ramin $1,69 \mathrm{~cm}$, rerata pertumbuhan jumlah daun 17,61 helai.

\section{Saran}

1. Untuk menjaga keberadaan lokasi genepool ramin dari gangguan manusia sebaiknya ditambahkan papan informasi di sekitar batas lokasi dan perlu dilakukan patroli disekitar lokasi genepool ramin karena ditemukan beberapa jerat yang dipasang untuk menjebak hewan seperti babi.

2. Untuk mengetahui pertumbuhan bibit ramin yang maksimal perlu dilakukan pengumpulan data setiap tahun dan berkala agar informasi yang tersaji lengkap dan selalu dilakukan penyulaman.

\section{DAFTAR PUSTAKA}

Argani, A., 2012. Keberhasilan Tumbuhan Anakan Kahoi (Shorea balangeran, Burck) di Kebun Penelitian dan Percobaan (KP2). Skripsi Program Studi Kehutanan Fakultas Kehutanan. Universitas Muhammadiyah Palangkaraya. Palangka Raya.
Balai Taman Nasional Sebangau., 2007. Rencana Pengelolaan Taman Nasional Sebangau Periode 2007-2026. Balai Taman Nasional Sebangau, Palangka Raya.

Badan Penelitian dan Pengembangan Kehutanan Kerjasama dengan ITTO., 2010. Panduan Penilaian NonDetrimantal Finding untuk Ramin (Gonystylus spp). Badan Penelitian dan Pengembangan Kehutanan kerjasama dengan ITTO, Bogor.

Komar., 2010, Karakteristik Hutan Rawa Gambut. Persyaratan Tumbuh Ramin. Review Hasil Penelitian dan Percobaan Lapangan. Departemen Kehutanan. Badan Penelitian dan Pengembangan Kehutanan. ITTO. Bogor.

Millang, S., Restu, M., Pongtandi, A., 2013. Pengaruh Jumlah Benih dan Diameter Bola Benih (Seedball) Terhadap Perkecambahan dan Pertumbuhan Benih Sengon (Paraserianthes falcataria (L) Nielsen) Di Lapangan. Prosiding Seminar Nasional Silvikultur I dan Pertemuan Ilmiah Tahunan Masyarakat Silvikultur Indonesia. Fakultas Kehutanan. Universitas Hasanudin. Makasar.

Sinay Hermalina, 2015. Peran Biologi dan Pendidikan Biologi dalam Menyiapkan Generasi Unggul dan Berdaya Saing Global. Fakultas Keguruan dan Ilmu Pendidikan Universitas Pattimura Ambon. Ambon.

Wagiso dan Abdullah. 2012. Monitoring Genepool Ramin Di Wilayah Kerja Resort Sebangau Hulu SPTN Wilayah I Palangka Raya. Palangka Raya.

Wagiso.Suyoko.Pakerti, A. dan Maryana, N. 2012. Laporan Monitoring Perkembangan Genepool Ramin. Taman Nasional Sebangau. Palangka Raya. 